ISSN: 1731-2221

DOI: http://dx.doi.org/10.21784/RH.2016.006

ROBERT KWAŚNIEWSKI, MAGDALENA JURCZUK

Państwowa Wyższa Szkoła Zawodowa we Włocławku

\title{
O psach i podatkach - historia i spółczesność
}

\section{About dogs and taxes - history and the present time}

\section{Streszczenie:}

Artykuł poświęcony został omówieniu specyficznej daniny publicznej obowiązującej w polskim systemie podatkowym jaką był kiedyś podatek, a dziś już opłata od posiadania psów. W publikacji przybliżono zarys historyczny tego podatku na świecie i w Polsce, wskazano na istotny moment przekształcenia przez ustawodawcę polskiego podatku od posiadania psów w opłatę oraz w sposób kompleksowy omówiono konstrukcję prawną opłaty zgodnie $\mathrm{z}$ regulacjami zawartymi w ustawie z dnia 12 stycznia 1991 roku o podatkach i opłatach lokalnych. Artykuł powstał $\mathrm{w}$ oparciu o analizę aktów prawnych, dostępnej literatury przedmiotu oraz przy wykorzystaniu orzecznictwa sądów administracyjnych.

\section{Słowa kluczowe:}

opłaty lokalne, opłata od posiadania psów, opodatkowanie psów, podatek od psów

\begin{abstract}
:
The article is about the specific public levy that existed in the Polish tax system as a tax. Nowadays it is the fee for dog ownership. The publication brings closer historical outline of this tax in the world and in Poland. It also shows the importance of transformation the Polish tax on the posession of dogs into the fee, and in a comprehensive way discusses the legal fee in accordance with the regulations on taxes and local fees in the Act
\end{abstract}


Robert Kwaśniewski, Magdalena Jarczuk - O psach i podatkach...

of 12 January 1991. The article is based on the analysis of legal acts, the available literature and case law of administrative courts

\section{Keywords:}

local fees, the fee for dog ownership, dogs taxation, a tax on dogs

\section{Wprowadzenie}

„But in this word nothing can be said to be certain, except death and taxes" ${ }^{1}$ - tak w liście adresowanym do Jeana Baptiste'a Leroy, datowanym na 13 listopada 1789 roku, napisał amerykański filozof Benjamin Franklin. W polskim tłumaczeniu cytat ten brzmi: „Na tym świecie pewne są tylko śmierć i podatki". Mimo upływu ponad 200 lat stwierdzenie tego uczonego jest nadal aktualne i często parafrazowane $\mathrm{w}$ publikacjach dotyczących podatków i prawa podatkowego. Podatki, które zaliczane są przez ustawodawcę do danin publicznych ${ }^{2}$ stanowią nieodzowny element każdego społeczeństwa. Także w Polsce już najwyższym akcie prawnym jakim jest Konstytucji Rzeczypospolitej Polskiej z dnia 2 kwietnia 1997 roku $^{3}$ ustawodawca stanowi, że „każdy jest zobowiązany do ponoszenia ciężarów publicznych i świadczeń publicznych, w tym podatków, określonych w ustawie".

W polskim systemie podatkowym, który nie oszukujmy się jest bardzo rozbudowany, istnieje zadziwiająca i dość nietypowa danina publiczna, jaką był podatek, a dziś już opłata od posiadania psów.

\footnotetext{
${ }^{1}$ Oryginalny tekst listu amerykańskiego filozofa i uczonego Benjamina Franklina do Jeana Baptiste'a Leroy: https://archive.org/stream/writingsofbenjam10franuoft/writingsofbenjam10franuo ft_djvu.txt.

${ }^{2} \bar{Z}$ godnie z art. 5 ust. 2 pkt 1 ustawy z dnia 27 sierpnia 2009 roku o finansach publicznych (tekst jedn.: Dz. U. z 2013r., poz. 885 z późn. zm.) do danin publicznych zalicza się: ,podatki, składki, opłaty, wpłaty z zysku przedsiębiorstw państwowych $i$ jednoosobowych spótek Skarbu Państwa oraz banków państwowych, a także inne świadczenia pieniężne, których obowiazek ponoszenia na rzecz państwa, jednostek samorząu terytorialnego, państwowych funduszy celowych oraz innych jednostek sektora finansów publicznych wynika z odrębnych ustaw".

${ }^{3}$ Dz. U. 1997 r., Nr 78 poz. 483 z późn. zm., uchwalona przez Zgromadzenie Narodowe w dniu 2 kwietnia 1997 r., przyjęta przez Naród w referendum konstytucyjnym w dniu 25 maja $1997 \mathrm{r}$.
} 
Opodatkowanie tylko psów, a nie np. kotów czy świnek morskich wzbudza wiele kontrowersji wśród społeczeństwa zarówno teraz, jak i w przeszłości, $\mathrm{z}$ chwilą jego zapoczątkowania i wprowadzenia. W artykule przybliżony zostanie zarys historyczny tego podatku na świecie i w Polsce, wskazany zostanie moment przeobrażenia przez ustawodawcę polskiego podatku od posiadania psów w opłatę oraz kompleksowo omówiona zostanie konstrukcja prawna obecnie obowiązującej daniny publicznej od posiadania psów, zgodnie $\mathrm{z}$ regulacjami prawnymi zawartymi $\mathrm{w}$ ustawie $\mathrm{z}$ dnia 12 stycznia 1991 roku o podatkach i opłatach lokalnych4.

\section{Rys historyczny podatku od posiadania psów}

Prawodawca demokratycznego państwa zobowiązany jest do daleko idącej rozwagi przy wprowadzaniu nowych obciążeń finansowych, w tym podatków i innych danin publicznych. Wiadomym jest, że władza publiczna nie jest w stanie spełniać swoich konstytucyjnych i ustawowych celów bez przymusowo pobranych i zgromadzonych środków finansowych. Podatki spełniające przede wszystkim funkcję fiskalną zapewniają dochód dla państwa, którego intencją jest kompleksowa realizacja zadań publicznych. Zakres podmiotowy i przedmiotowy podatków na przestrzeni wieków dynamicznie się zmienia i rozszerza. Jest to wynikiem ciągłego pojawiania się nowych form prawnych $\mathrm{w}$ obrocie gospodarczym oraz dążenia ustawodawcy do powszechnego opodatkowania we wszystkich sferach, w których osiągany jest dochód lub posiadany jest określony majątek. Także rozwój społeczny niesie za sobą nieustannie rosnące potrzeby zbiorowe, co wpływa na zwiększenie wydatków publicznych, czego następstwem jest konieczność pozyskiwania nowych państwowych źródeł dochodów, a to dokonuje się poprzez wprowadzenie do systemu podatkowego nieznanych dotychczas danin publicznych ${ }^{5}$.

Dość nietypową i zadziwiającą daniną publiczną obowiązującą w polskim systemie podatkowym jest podatek, a dziś już opłata od posiadania psów, która obecnie została uregulowana w ustawie $\mathrm{z}$ dnia

${ }^{4}$ Tekst jedn.: Dz. U. z 2016 r., poz. 716 z późn. zm., dalej również jako „ustawa”.

${ }^{3}$ A. Krzywoń, Podatki i inne daniny publiczne w Konstytucji Rzeczypospolitej Polskiej, Wojskowa Drukarnia w Łodzi, Warszawa 2011, s. 11. 
Robert Kwaśniewski, Magdalena Jarczuk - O psach i podatkach...

12 stycznia 1991 roku o podatkach i opłatach lokalnych. Historia tego szczególnego podatku sięga jednak kilku wieków wstecz.

W średniowiecznej Europie zasadniczym dowodem na istnienie opodatkowania psów były świadczenia ciążące na osobach, które posiadały owe stworzenie. Jak wiadomo niegdyś szlachecki pies znajdował się na znacznie wyższym szczeblu $\mathrm{w}$ hierarchii społeczeństwa feudalnego niż poddany czy służący. Fundamentalną różnicą między nimi był fakt, iż poddany bądź służący przysługiwali panu z mocy samego boskiego prawa. Natomiast fakt posiadania psa wiązał się przede wszystkim $\mathrm{z}$ wydatkami, wpierw z wydatkami poniesionymi na jego zakup, a potem na utrzymanie. Posiadanie psa było kosztowe, a co za tym idzie nie każdy mógł sobie na to pozwolić. Z czasem utrwalone zostało charakterystyczne powiedzenie „zejść na psy", które pojmowane było jako zrujnowanie osobistej gospodarki poprzez przesadne wydatki na swoje czworonogi ${ }^{6}$.

Podatek od trzymania psa (termin używany w prawodawstwie niemieckojęzycznym, anglosaskim i frankofońskim) był pomysłem Anglików powstałym już w drugiej połowie XVIII wieku. Posiadanie psa w Anglii przyjęto jako przejaw luksusu, ponieważ powszechnie wiadomo było jakie wiążą się z tym koszty, a użyteczność tych zwierząt była znikoma. Na luksus $\mathrm{w}$ przedstawionej formie decydowali się jedynie ci, których było stać na uiszczanie na rzecz państwa daniny publicznej z tym związanej. Kolejną przesłanką, która spowodowała opodatkowanie czworonogów, była próba zmniejszenia ilości zwierząt $\mathrm{w}$ miastach ze względów społecznych i sanitarnych. Wprowadzenie podatku miało zniechęć społeczeństwo do trzymania psów przede wszystkim na terenie większych miast7.

28 październik 1810 roku cesarz Fryderyk Wilhelm III podpisując edykt o podatku od nowej konsumpcji i luksusu (Edikt über die neuen Consumptions und Luxus-Steuern) wprowadził podatek od posiadania psów, który zaczął obowiązywać po raz pierwszy w Prusach, a tym samym na polskich ziemiach zachodnich. Początkowo społeczeństwo bez żadnych sprzeciwów zaakceptowało nową daninę publiczną. Najlepiej potwierdzają to słowa: „podatki należy płacić tak chętnie, jakby się dawało ukochanej prezent” („Man soll dem Staat die Steuern zahlen, wie Man ener Geliebten

${ }^{6}$ C. Kosikowski, J. Matuszewski, Opodatkowanie posiadania psów czyli płacz ze śmiechu wokót buty, Dom Wydawniczy ABC, Warszawa 2002, s. 157.

${ }^{7}$ Ibidem. s. 158 
Geschenke darbringt"). Podatki $\mathrm{w}$ tym czasie miały na celu ratowanie i naprawę państwa po katastrofie napoleońskiej, a więc wprowadzenie nowej daniny nie budziło żadnych zastrzeżeń wśród ludu. Podatek ten miał charakter prewencyjny, gdyż jego głównym celem była ochrona państwa przed panującą wścieklizną wśród włóczących się psów. W związku z tym wprowadzono obowiązek rejestracji psów polegający na tym, że każde zwierzę musiało mieć doczepiony do obroży blaszany znaczek z nadanym mu numerem. Argumentem przychylającym się za opodatkowaniem psa była kontrola ich liczebności, a następnie ochrona przed chorobami przenoszonymi przez te zwierzęta. $\mathrm{W}$ praktyce podatek ten pełnił przede wszystkim typową funkcję fiskalną8.

Opodatkowanie psów w tych czasach pełniło funkcję podatku od luksusu oraz dotyczyło wyłącznie psów domowych. Głównym powodem wprowadzenia tego podatku było założenie, że właściciel psa jest osobą na tyle majętną i będzie w stanie zapłacić ciążący na nim podatek z tego tytułu9. Wprowadzenie takiej daniny publicznej miało na celu wzmocnić budżet państwa, co bezsprzecznie pełniło istotną funkcję fiskalną. Należy zaznaczyć, że $\mathrm{w}$ przepisach prawa podatkowego ustawodawca przewidział szereg zwolnień dotyczących podatku od posiadania psów. Owe zwolnienia w głównej mierze dotyczyły psów pasterskich, psów wykorzystywanych do strzeżenia gospodarstw rolnych oraz psów chowanych dla celów wyłącznie zawodowych. Użyteczność psa w mieście nie była zbyt duża, co za tym idzie konieczność ich posiadania $\mathrm{w}$ głównej mierzę rodziła się $\mathrm{z}$ chęci zaspokajania tylko i wyłącznie własnych potrzeb emocjonalnych. W zasadzie pies w miastach stanowił maskotkę damy bądź zaspokajał zwykły snobizm pana, który za wszelką cenę chciał pokazać swoją majętność ${ }^{10}$.

Od schyłku XIX wieku opodatkowanie psów nabrało odmiennych funkcji oraz charakteru. Mimo że podatek od posiadania psów nadal uważany był jako podatek od luksusu, to świadczenie to stało się nie tyle świadczeniem skarbowym, a miało charakter sanitarno-policyjny.

\footnotetext{
${ }^{8}$ Ibidem, s. 159.

${ }^{9}$ J. Politowicz, Funkcje i efektywność opłaty od posiadania psów [w:] Studenckie Prace Prawnicze, Administratywistyczne i Ekonomiczne 15, Wydawnictwo Uniwersytetu Wrocławskiego, Wrocław 2014, s. 110.

${ }^{10}$ C. Kosikowski, J. Matuszewski, Opodatkowanie posiadania psów... op.cit., s. 161.
} 
Robert Kwaśniewski, Magdalena Jarczuk - O psach i podatkach...

Wprowadzony w 1897 roku na teren całego imperium carskiego podatek nabrał wyraźniejszego charakteru. Władza w stosunku do tego podatku przewidziała dodatkową zasadę dobrowolności opodatkowania, która została przyznana jedynie władzom samorządowym. W praktyce jednakże możliwość ta była dość ograniczona poprzez nacisk ze strony administracji rządowej, aby władze samorządowe wprowadzały sugerowany podatek na swoim terenie, a nie rezygnowały z niego. Świetnym tego przykładem jest miasto Łódź, gdzie tuż po wprowadzeniu nowych zasad postanowiono skorzystać z możliwości niewdrażania podatku od posiadania psa. Niestety nie dało się tego zrealizować, gdyż po intensywnych korespondencjach z gubernatorem piotrkowskim miasto zobowiązane było ulec i podatek wprowadzić. Władze miasta argumentując swoje stanowisko uznały koszt wprowadzenia i dalszego realizowania spraw związanych z daniną publiczną za zbyt wysoki, co w rezultacie prowadziłoby do przewyższania kosztów funkcjonowania przedsięwzięcia nad uzyskiwanymi dochodami $\mathrm{z}$ tego tytułu. Zaś wśród argumentów, które przedstawiły władze carskie figurował fakt wcześniejszego istnienia podatku oraz pełnienie przez ten podatek funkcji administracyjno-porządkowej, natomiast pozyskiwanie środków finansowych nie było jego głównym celem ${ }^{11}$.

$\mathrm{Z}$ dniem wejścia $\mathrm{w}$ życie ustawy $\mathrm{z}$ dnia 19 grudnia 1975 r. o niektórych podatkach i opłatach terenowych ${ }^{12}$ gminne i miejski rady narodowe wyposażone zostały, zgodnie $\mathrm{z}$ art. 18, w kompetencję decydowania o wprowadzeniu bądź rezygnacji z podatku od posiadania psów na terenie swojej gminy. Organy te miały prawo do rezygnacji z tego podatku w każdym dogodnym momencie. Należy zaznaczyć, iż podatek był wtedy daniną fakultatywną. Do kompetencji rad narodowych (miejskich lub gminnych) należało zgodnie $\mathrm{z}$ tą ustawą określenie wysokości podatku, wprowadzanie zwolnień podatkowych oraz ustalenie terminu płatności i sposobu poboru podatku.

Podatek od posiadania psów przez długi okres czasu był podatkiem fakultatywnym, a jego wysokość uzależniona była od ilości trzymanych zwierząt. Należy wspomnieć, że ustawodawca w przepisach ww. ustawy przewidział pewne wyłączenia z opodatkowania. Podatkiem od posiadania psów nie obejmowano wówczas psów należących do personelu misji

${ }^{11}$ Ibidem, s. 164.

${ }^{12}$ Dz. U. z 1975 r., Nr 45, poz. 229 z późn. zm. 
dyplomatycznych lub urzędów konsularnych państw obcych pod warunkiem wzajemności, psów będących własnością kalek (niedołężnych, niewidomych i głuchoniemych), które służyły im do pomocy w życiu codziennym oraz psów utrzymywanych na terenie gmin $\mathrm{w}$ celu pilnowania gospodarstw rolnych. Wyłącznie to przysługiwało tylko na jednego psa w gospodarstwie rolnym, natomiast osoba będąc właścicielem drugiego i następnego czworonoga była zobowiązana do ich opodatkowania, które odbywało się zgodnie $\mathrm{z}$ obowiązującymi na ten czas przepisami prawa. Ostatnim zwolnieniem dotyczącym omawianego podatku był czworonogi utrzymywane wyłącznie w celu pilnowania stad pasterskich. Co więcej, gminne i miejskie rady narodowe wprowadzając analizowaną daninę publiczną zobowiązane były wprowadzić ulgę w wysokości co najmniej $50 \%$ ustalonej stawki podatku z racji posiadania jednego psa przez rencistów, emerytów oraz inwalidów, którzy samodzielnie prowadzą gospodarstwo domowe ${ }^{13}$.

Istotne zmiany w podatku od posiadania psów wprowadziła ustawa z dnia 14 marca 1985 roku o podatkach i opłatach lokalnych ${ }^{14}$, która fakultatywny podatek zastąpiła obligatoryjnym, co niosło ze sobą ogromną falę krytyki wśród społeczeństwa. Zwracano między innymi uwagę na to, że za obligatoryjnym charakterem tego podatku nie przemawiają żadne względy fiskalne, gdyż wpływy z tego podatku są niewielkie. Wynikało to, nie tylko z niewielkiej wysokości podatku, ale przed wszystkim z trudności zorganizowania efektywnego poboru podatku15.

Ustawodawca w tym akcie prawnym wprost zilustrował podmiot, na którym ciążył obowiązek podatkowy w zakresie tego podatku, stwierdzając, że jest to osoba fizyczna posiadająca psa. Takiej regulacji nie zawierała poprzednia ustawa podatkowa. Prawodawca całkowicie przekształcił zwolnienia podatkowe wyłączając spod opodatkowania osoby, które

${ }^{13}$ C. Kosikowski, E. Ruśkowski, Finanse i prawo finansowe, Wyd. 3 z aneksem, Warszawa 1994, s. 189-191.

${ }^{14}$ Dz. U. z 1985 r., Nr 12, poz. 849 z późn. zm.

${ }^{15}$ K. Lasiński-Sulecki, W. Morawski, Komentarz do art. 18 a ustawy o podatkach $i$ opłatach lokalnych., [w:] T. Brzezicki, K. Lasiński-Sulecki, W. Morawski, J. Wantoch-Rekowski, Ustawa o podatkach $i$ opłatach lokalnych. Komentarz, ODDK Spółka z ograniczoną odpowiedzialnością Spółka komandytowa, Gdańsk 2013, s. 479. 
Robert Kwaśniewski, Magdalena Jarczuk - O psach i podatkach...

posiadają psy, a jednocześnie są członkami personelu przedstawicielstw dyplomatycznych i urzędów konsularnych oraz innych osób zrównanych z nimi na podstawie umów, ustaw bądź zwyczajów międzynarodowych, jeśli nie mają obywatelstwa polskiego oraz nie posiadają miejsca stałego pobytu na terytorium Polskiej Rzeczypospolitej Ludowej, $\mathrm{z}$ tym że nadal ustawodawca zaznacza fakt utrzymania warunku wzajemności. Istotnym jest, że w art. 12 ust. 5 niniejszej ustawy prawodawca wprowadził przepis, który stanowił, że wpływy z tytułu podatku od posiadania psów stanowiły dochody funduszu miejskiego lub gminnego ${ }^{16}$

Niezwykle ważnym jest, że za powrotem obligatoryjnego podatku od posiadania psów nie przemawiały względy fiskalne, gdyż dochody z omawianej daniny publicznej był stosunkowo niewielkie ${ }^{17}$. Niektórzy autorzy uznawali ten podatek za "hańbiący cały system podatkowy, a podawanie argumentów fiskalnych i pozafiskalnych mających uzasadnić celowość tego podatku" całkowicie za żałosne ${ }^{18}$.

Zasadniczym powodem, przez który gminy nie chciały wprowadzać podatku na swój teren, były problemy z efektywnym poborem należności od podmiotów, na których faktycznie spoczywał obowiązek uiszczenia odpowiedniej kwoty podatku z racji posiadania psa. Podatnicy nie zawsze wywiązywali się z ciążącego na nich obowiązku podatkowego, zatem organy podatkowe gminy zmuszone były do wprowadzenia kontroli, która zwiększała koszty poboru podatku. Rodziło to stosunkowo wysokie wydatki przy niskich dochodach i stało po prostu się dla gmin nieopłacalne. Przez lata rodziły się wielorakie pomysły, przy zastosowaniu, których gmina uniknęłaby wielu problemów związanych z poborem podatku od posiadania psów, między innym powiązanie poboru daniny publicznej z wydawaniem oznaczeń wszczepianych psom. Jednym z ciekawszych rozwiązań było nałożenie obowiązku poboru podatku na weterynarzy, którzy szczepili psy, a w przypadku terenów wiejskich obowiązek ten ciążyłby na sołtysach. Istotnym jest, że niegdyś $\mathrm{w}$ niektórych gminach dokument świadczący o zapłacie podatku od posiadania psów dawał możliwość do nieodpłatnego szczepienia psów przeciw wściekliźnie, w czasie akcji szczepienia

${ }^{16}$ C. Kosikowski, E. Ruśkowski, Finanse i prawo finansowe ...op.cit., s. 190.

${ }^{17}$ L. Etel, S. Presnarowicz, Podatki $i$ opłaty samorzadowe. Komentarz, Dom Wydawniczy ABC, Warszawa 2003, s. 102.

${ }^{18}$ C. Kosikowski, E. Ruśkowski Finanse i prawo finansowe...op.cit,, s. 190. 
organizowanych przez daną gminę. Natomiast $\mathrm{w}$ takiej sytuacji danina publiczna nazywana $\mathrm{w}$ przepisach prawa podatkiem nabierała cechę odpłatności, która jest elementem opłaty ${ }^{19}$.

Kolejne zmiany w podatku od posiadania psów nastąpiły z dniem wejścia w życie ustawy z dnia 26 listopada 1998 roku o dochodach jednostek samorządu terytorialnego ${ }^{20}$ (ustawa obowiązywała w latach 1999-2003). Ustawa ta wprowadziła do przepisów prawa kolejną możliwość zwolnień w podatku od posiadania psów. Mianowie art. 57 ww. ustawie pozwalał radom gmin $\mathrm{w}$ na wprowadzenie na swoim terenie zwolnienia wszystkich mieszkańców gminy z podatku od posiadania psów, a także umożliwiał wprowadzenie innych zwolnień. Wątpliwości budziła jednak forma jaką zastosował prawodawca $\mathrm{w}$ tym przepisie. Według utrwalonej linii orzeczniczej Naczelnego Sądy Administracyjnego oraz Sądu Najwyższego wprowadzone zwolnienie winno mieć charakter kategorialny. Wprowadzenie do struktury podatku od posiadania psów zwolnienia o charakterze ogólnym zaburzało rozumienie pojęcia zwolnienia podatkowego ${ }^{21}$.

$\mathrm{Z}$ dniem wejścia w życie ustawy z dnia 30 października 2002 roku o zmianie ustawy o podatkach i opłatach lokalnych oraz zmianie niektórych innych ustaw $^{22}$ ponownie wprowadzono obligatoryjności podatku od posiadania psów. Ustawodawca uchylił także artykuł dotyczący zwolnień podmiotowych z daniny publicznej dotyczący wszystkich mieszkańców gminy.

\section{Kiedyś podatek dziś opłata od posiadania psów}

Przełomowym momentem w historii podatku od posiadania psów było jego zniesienie z dniem 1 stycznia 2008 roku. Dokonano tego na podstawie ustawy z dnia 7 grudnia 2006 roku o zmianie ustawy o podatkach i opłatach lokalnych oraz zmianie niektórych innych ustaw ${ }^{23}$. Ważnym jest,

${ }^{19}$ K. Lasiński-Sulecki, W. Morawski, Komentarz do art. 18 a ustawy o podatkach i optatach lokalnych ... op.cit., s. 479-480.

${ }^{20}$ Dz. U. z 1998r., Nr 150, poz. 983 z późn. zm.

${ }^{21} \mathrm{~K}$. Lasiński-Sulecki, W. Morawski, Komentarz do art. 18 a ustawy o podatkach i optatach lokalnych ... op. cit., s. 480.

${ }^{22}$ Dz. U. z 2002 r., Nr 200, poz. 1683.

${ }^{23}$ Dz. U. z 2006 r., Nr 249, poz. 1828. 
Robert Kwaśniewski, Magdalena Jarczuk - O psach i podatkach...

że funkcjonowanie podatku od posiadania psów było $\mathrm{w}$ tych czasach masowo krytykowane przez obywateli oraz samorządy gmin. Podatnicy często na przedmiot opodatkowanie reagowali śmiechem, który spowodowany był niedowierzaniem, że opodatkowaniu podlega posiadanie psów. Zasadniczym argumentem, który nieustannie podnoszono był fakt, że wpływy $\mathrm{w}$ omawianej daniny publicznej były marginalne. Sugerowane rozwiązania z zewnątrz całkowitego usunięcia opodatkowania psów bądź wprowadzenie fakultatywnego charakteru daniny publicznej stały się dla ustawodawcy przewodnie. Kwestie niezadowolenia społecznego widniało na tak wysokim poziomie, że konieczność zmian w tej dziedzinie była niezbędna ${ }^{24}$

Istotnym jest, że ustawodawca nie zrezygnował całkowicie z omawianej daniny publicznej, natomiast przekształcił ją $\mathrm{w}$ opłatę o charakterze fakultatywnym, która uregulowana została w art. 18a ustawy zdnia 12 stycznia 1991 roku o podatkach i opłatach lokalnych. Charakterystycznym dla opłaty jest stwierdzenie, że to danina publiczna, która posiada wszystkie cechy podatku (tj. ogólny i przymusowy charakter, bezzwrotność, jednostronność ustalania, przewłaszczenie, forma pieniężna) oprócz jednej, którą jest nieodpłatności. Opłata charakteryzuje się cechą odpłatności ${ }^{25}$. Zaskakujące jest jednak, że współcześnie stosowana danina publiczna posiada wszystkie cechy podatku, co przede wszystkim ukazane jest $\mathrm{w}$ braku charakteru odpłatności, natomiast ewidentnie cechuję ją nieodpłatnośćc ${ }^{26}$. Analiza katalogu opłat lokalnych zawartych w ustawie pozwala na zasadne stwierdzenie, że niektóre świadczenia posiadają wszystkie cechy podatku, a najlepszym tego przykładem jest opłata od posiadania psów, która do niedawna widniała jako podatek. Na myśl nasuwa się wtedy pytanie: dlaczego prawodawca świadczenia te postanowił nazywać opłatami, gdy w istocie rzeczy są podatkami i wszystkie cechy podatków spełniają ${ }^{27}$ ?

${ }^{24}$ J. Politowicz, Funkcje i efektywność oplaty od posiadania psów ... op.cit., s. 111 .

25 B. Brzeziński, Wprowadzenie do prawa podatkowego, TNOiK Dom Organizatora, Toruń 2008, s. 29.

${ }^{26} \mathrm{~K}$. Lasiński-Sulecki, W. Morawski, Komentarz do art. 18 a ustawy o podatkach i optatach lokalnych ... op.cit., s. 480.

${ }^{27}$ L. Etel, R. Dowgier, Podatki i oplaty lokalne - czas na zmiany, Naukowa Rada Wydawnicza Temida 2, Białystok 2013, s. 96. 


\section{Konstrukcja prawna obecnie obowiązującej opłaty od posiadania psów}

Zgodnie z umocowaniem zawartym w art. 18a ustawy o podatkach i opłatach lokalnych rada gminy może wdrożyć na terenie swojej gminy opłatę od posiadania psów. W ten sposób, z dniem 1 stycznia 2008 roku, katalog opłat lokalnych został poszerzony o dodatkową fakultatywną daninę publiczną, która może - lecz nie musi - być wprowadzona w formie stosownej uchwały ${ }^{28}$. Ustawodawca $\mathrm{w}$ tym przepisie wyraźnie wskazuje, że podmiotem na którym ciąży obowiązek podatkowy z tytułu opłaty od posiadania psów jest osoba fizyczna posiadająca minimum jednego psa. Natomiast w sytuacji, gdy pies jest własnością osoby prawnej lub jednostki organizacyjne nieposiadającej osobowości prawnej to obowiązek, ten nie powstanie ${ }^{29}$. Warto zwrócić uwagę na wyrok Naczelnego Sądu Administracyjnego z dnia 20 sierpnia 2002 roku ${ }^{30}$, zgodnie z którym w sytuacji „kiedy pies stanowi majątek spółki cywilnej, wspólnik tej spółki pozbawiony jest nad nim takiego władztwa, które uzasadniałoby jego obowiązek podatkowy". Istotnym jest, że przetoczony wyrok zapadł na podstawie nieobowiązujących już przepisów prawa, natomiast zachował swoją aktualność w literaturze przedmiotu. Zaznaczyć należy, że spółka nie mając podmiotowości prawnej nie może być właścicielem psa, co w rezultacie sprowadza się do faktu, że posiadaczami są jej wspólnicy, którzy powinni być podatnikami. $\mathrm{W}$ takim przypadku niewiadomo również czy odpowiedzialność za zobowiązanie podatkowe ciąży solidarnie na wszystkich wspólnikach, czy też może być rozbite na poszczególne jednostki. Ze względu na pewnego rodzaju ułomność regulacji uznaję się, że opłata ta nie może być nałożona na wspólników spółki, a tym bardziej na samą spółkę 31 .

${ }^{28}$ D. Michta, L. Pankrac, Podatki i optaty lokalne. Komentarz. Orzecznictwo, Warszawa 2015, s. 118.

${ }^{29} \mathrm{~K}$. Lasiński-Sulecki, W. Morawski, Komentarz do art. 18 a ustawy o podatkach i oplatach lokalnych ... op.cit., s. 481.

${ }^{30}$ Sygn. III SA 3153/01, CBOSA.

${ }^{31} \mathrm{~K}$. Lasiński-Sulecki, W. Morawski, Komentarz do art. 18 a ustawy o podatkach i oplatach lokalnych ... op.cit., s. 481. 
Opłatą od posiadania psów obciążone są tylko osoby fizyczne, u których zwierzę faktycznie przebywa, a nie osoby, które tymczasowo sprawuję nad nim opiekę. Zatem pożyczenie psa czy też czasowa opieka nad zwierzęciem nie będzie stanowić podstaw do ubiegania się o należności podatkowe. Niezależnie od tego, czy pies znajduje się na posesji prawowitych właścicieli czy w mieszkaniu chwilowego opiekuna obowiązek podatkowy spoczywa na faktycznym właścicielu ${ }^{32}$.

Przedmiotem opodatkowania jest posiadanie psa na terenie danej gminy. Natomiast problem rodzi się w sytuacji, gdy osoba fizyczna odda go w posiadanie zależne, które uregulowane jest $\mathrm{w}$ art. 336 ustawy z dnia 23 kwietnia 1964 roku - Kodeks cywilny ${ }^{33}$. Ustawodawca wyróżnia:

1) posiadanie samoistne - posiadaczem rzeczy jest ten, kto nią faktycznie włada jak właściciel (posiadacz samoistny),

2) posiadanie zależne - posiadaczem rzeczy jest ten, kto nią faktycznie włada jak najemca, dzierżawca, użytkownik, zastawnik lub mający inne prawo, z którym wiąże się władztwo nad cudzą rzeczą (posiadacz zależny).

W związku z tym, że zgodnie z art. 337 Kodeksu cywilnego posiadacz samoistny nie traci posiadania $\mathrm{w}$ sytuacji, gdy odda drugiemu rzecz w posiadanie zależne, nie jest jasne na kim ciąży obowiązek podatkowy w zakresie opłaty od posiadania psów. W zaistniałej sytuacji zauważane są tu dwa podmioty, które teoretycznie mogłyby być podatnikami.

Następna komplikacja powstaje $\mathrm{w}$ sytuacji, gdy pies jest we władaniu kilku osób np. członków rodziny. W przepisach prawa nie jest jasno powiedziane komu przypisać obowiązek podatkowy w zaistniałych okolicznościach. Jedynym praktycznym rozwiązaniem, które pozwala na rozwiązanie problemu jest działanie na zasadzie analogii przepisów art. 3 ust. 3 i 4 ustawy, które dotyczą podatku od nieruchomości. Regulacje te dotyczą zasad odpowiedzialności solidarnej za zobowiązania podatkowe. Jednakże zastosowanie takiego rozwiązania jest dość ryzykowne. Istotnym jest, że wnioskowaniem $\mathrm{z}$ analogii $\mathrm{w}$ materialnym prawie podatkowym należy posługiwać się z wielką ostrożnością. $\mathrm{W}$ sytuacjach, gdy korzystanie z tej zasady mogłoby prowadzić do zwiększenia zakresu obowiązków podatkowych, niezbędne jest jej wykluczenie. Wartym podkreślenia jest fakt,

32 J. Politowicz, Funkcje i efektywność oplaty od posiadania psów ...op.cit., s. 112.

${ }^{33}$ Tekst jedn.: Dz. U. z 2015 r. poz. 1844 z późn. zm. 
że orzecznictwo dotyczącym opłaty od posiadania psów bazuje na przepisach prawa cywilnego ${ }^{34}$.

Stawka podatkowa to instrument, który służy do określenia kwoty należności podatkowej $\mathrm{w}$ stosunku do podstawy opodatkowania ${ }^{35}$. Samorządowe organy stanowiące gminy decydują o wysokości opłat lokalnych stosując ograniczenia przyjęte przez ustawodawcę. Zgodnie z art. 19 pkt 1 ustawy o podatkach i opłatach lokalnych rada gminy zobowiązana jest do określenia wysokość opłat z zachowaniem pewnych granic. Istotnym jest, że rady gmin podejmując uchwałę w sprawie określanie stawek nie mogą przekraczać górnych granic określonych w ustawie. Natomiast, zgodnie z art. 20 ustawy, w przypadku nieuchwalenia przez radę gminy stawek opłat lokalnych stosuje się stawki, które obowiązywały w roku poprzedzającym rok podatkowy. Ustawodawca początkowo przyjął w stosunku do opłaty od posiadania psów stawkę, która nie może przekroczyć 100 zł rocznie od jednego psa, jednakże trzeba zaznaczyć, że co roku obowiązująca stawka ulega zmianie.

Zgodnie $\mathrm{z}$ art. 20 ustawy górne granice stawek obowiązujące w danym roku podatkowym ulegają corocznej zmianie w stosunku do następnego roku podatkowego. Ustawodawca w zakresie określania opłat lokalnych określił wyłącznie górne granice stawek, natomiast w pozostałym obszarze pozwala na samodzielne działania gminy. Dodatkowo ustawa zawiera wskaźnik, który okazał się niezbędny do waloryzacji górnych kwotowych stawek dotyczących opłat. Mowa jest o wskaźniku cen towarów i usług konsumpcyjnych w pierwszym okresie półrocza roku, w którym stawki te ulegają zmianie, w porównaniu do analogicznego przedziału czasowego roku poprzedniego. Tymczasem wskaźnik ten wyznacza się na podstawie komunikatu Prezesa Głównego Urzędu Statystycznego, który jest ogłaszany w terminie 20 dni po upływie pierwszego półrocza w Dzienniku Urzędowym Rzeczypospolitej Polskiej „Monitor Polski”. Limity stawek kwotowych ogłaszane są przez ministra właściwego do spraw finansów publicznych w formie obwieszczenia, a następnie informacje te zamieszczane są w Dzienniku Urzędowym Rzeczypospolitej Polskiej

\footnotetext{
${ }^{34}$ K. Lasiński-Sulecki, W. Morawski, Komentarz do art. 18 a ustawy o podatkach i optatach lokalnych... op.cit., s. 481.

${ }^{35}$ C. Kosikowski, J. Matuszewski, Opodatkowanie posiadania psów... op.cit., s. 234.
} 
Robert Kwaśniewski, Magdalena Jarczuk - O psach i podatkach...

„Monitor Polski”. Jak kształtowały się maksymalne stawki opłaty od posiadania psów przedstawia następująca tabela:

Tabela 1. Maksymalne stawki opłaty od posiadania psów w latach 2008-2016.

\begin{tabular}{|c|c|c|}
\hline lp. & Rok & Stawka opłaty w złotych \\
\hline 1. & 2008 & 100 \\
\hline 2. & 2009 & $104,20^{36}$ \\
\hline 3. & 2010 & $107,85^{37}$ \\
\hline 4. & 2011 & $110,66^{38}$ \\
\hline 5. & 2012 & $115,31^{39}$ \\
\hline 6. & 2013 & $119,93^{40}$ \\
\hline 7. & 2014 & $121,01^{41}$ \\
\hline
\end{tabular}

\footnotetext{
${ }^{36}$ Obwieszczenie Ministra Finansów z dnia 29 lipca 2008 r. w sprawie górnych granic stawek kwotowych podatków i opłat lokalnych w 2009 r. M.P. 2008 nr 59 poz. 531.

${ }^{37}$ Obwieszczenie Ministra Finansów z dnia 3 sierpnia 2009 r. w sprawie górnych granic stawek kwotowych podatków i opłat lokalnych w 2010 r. M.P. 2009 nr 52 poz. 742 .

${ }^{38}$ Obwieszczenie Ministra Finansów z dnia 30 lipca 2010 r. w sprawie górnych granic stawek kwotowych podatków i opłat lokalnych w 2011 r. M.P. 2010 nr 55 poz. 755 .

${ }^{39}$ Obwieszczenie Ministra Finansów z dnia 19 października 2011 r. w sprawie górnych granic stawek kwotowych podatków i opłat lokalnych w 2012 r. M.P. $2011 \mathrm{nr} 95$ poz. 961.

${ }^{40}$ Obwieszczenie Ministra Finansów z dnia 2 sierpnia 2012 r. w sprawie górnych granic stawek kwotowych podatków i opłat lokalnych w 2013 r. M.P. 2012 poz. 587.

${ }^{41}$ Obwieszczenie Ministra Finansów z dnia 7 sierpnia 2013 r. w sprawie górnych granic stawek kwotowych podatków i opłat lokalnych w 2014 r. M.P. 2013 poz. 724.
} 


\begin{tabular}{|c|c|c|}
\hline 8. & 2015 & $121,50^{42}$ \\
\hline 9. & 2016 & $120,05^{43}$ \\
\hline
\end{tabular}

Źródło: Opracowanie własne na podstawie obwieszczeń ministra właściwego do spraw finansów publicznych.

Początkową stawkę opłaty od posiadania psów prawodawca określił w ustawie z dnia 7 grudnia 2006 roku o zmianie ustawy o podatkach i opłatach lokalnych oraz zmianie niektórych innych ustaw. Z dniem wejścia w życie opłaty od posiadania psów roczna stawka omawianej daniny publicznej nie mogła przekraczać 100 zł od jednego psa. Następnie od 2008 roku maksymalna wysokość opłaty od posiadania psów nieustannie rosła, a dopiero w roku bieżącym została nieco obniżona (dokładnie o 1,45 zł) i obecnie utrzymuje się na poziomie $120,05 \mathrm{zł}$

Szczegóły dotyczące zasady poboru oraz terminy płatności opłaty od posiadania psów powinna zawierać uchwała, którą zobowiązana jest podjąć rada gminy. Wobec tego, że ustawa milczy w tej materii, słuszne jest, aby samorządowe organy stanowiące gminy skrupulatnie określiły zasady dotyczące poboru omawianej daniny publicznej i terminów jej zapłaty. Głównym tego celem jest uniknięcie ewentualnych luk oraz wątpliwości w przyszłym stosowaniu uchwały. Istotnym jest, że obowiązek uiszczenia płatności związanych z omawianą opłatą powstaje z mocy prawa, zatem należność winna być uregulowana bez wezwania obowiązanego do jej zapłaty przez organ podatkowy. Nie występuje tu żadna decyzja wymiarowa. Zasadą jest, że to właśnie na podatniku ciąży obowiązek zapłaty wskazanej opłaty i to bez wcześniejszego zawiadamiania o tej powinność przez odpowiednie instytucje państwowe. Ponadto opłata od posiadania psów jest daniną roczną, toteż powinna być pobierana raz w roku od jednego psa ${ }^{44}$.

${ }^{42}$ Obwieszczenie Ministra Finansów z dnia 7 sierpnia 2014 r. w sprawie górnych granic stawek kwotowych podatków i opłat lokalnych w 2015 r. M.P. 2014 poz. 718.

${ }^{43}$ Obwieszczenie Ministra Finansów z dnia 5 sierpnia 2015 r. w sprawie górnych granic stawek kwotowych podatków i opłat lokalnych w 2016 r. M.P. 2015 poz. 735 .

${ }^{44}$ A. Ciąglewicz-Miśta, N. Ciąglewicz, A. Talik, Podatki i optaty lokalne. Komentarz. Projekty uchwat. Orzecznictwo, C.H.BECK, Warszawa 2011, s. 69. 
Robert Kwaśniewski, Magdalena Jarczuk - O psach i podatkach...

Ze względu na fakt, że obowiązek podatkowy zapłaty daniny publicznej, który ciąży na konkretnej osobie może ustać w trakcie trwania roku podatkowego, za logiczne uważa się przyjęcie zasady proporcjonalność zmniejszenia opłaty. Oczywistym jest, że zachodzi to w sytuacji utraty psa ${ }^{45}$. Analogicznie przyjmując nabycie psa $\mathrm{w}$ trakcie roku podatkowego skutkować może współmiernym pomniejszeniem opłaty do okresu, w którym zwierzę faktycznie się pojawiło. Należy zaznaczyć, że przedstawione rozwiązanie nie jest obligatoryjne, natomiast rada gminy ma pełne prawo do jego wykorzystania ${ }^{46}$.

Jak stanowi art. 19 pkt 2 ustawy o podatkach i opłatach lokalnych rada gminy w odniesieniu do opłat objętych ustawą ma prawo do:

1) zarządzania poboru daniny publicznej $w$ drodze inkasa,

2) wskazania wybranych inkasentów,

3) do określenia wysokość wynagrodzenia inkasentów.

Jak trafnie uznał Naczelny Sąd Administracyjnym w wyroku z dnia 21 września 2007 roku $^{47}$ „status inkasenta zobowiązanego do poboru podatków i opłat stanowiących dochód budżetu jednostek samorządu terytorialnego powinien wynikać wprost $\mathrm{z}$ aktu prawa miejscowego, jakim jest stosowna uchwała rady gminy wydanej na podstawie upoważnienia ustawowego". Zarządzenia poboru omawianej daniny publicznej w drodze inkasa nie jest równoznaczne z określeniem wynagrodzenie za inkaso w sytuacji, gdy w uchwale rady gminy nie ma stosownej wzmianki na ten temat ${ }^{48}$. Potwierdzeniem powyższych słów jest orzeczenie Wojewódzkiego Sądu Administracyjnego w Opolu z dnia 14 lipca 2009 roku ${ }^{49}$, w którym czytamy, że „brzmienie art. 19 pkt 2 ustawy o podatkach i opłatach lokalnych nie przewiduje obligatoryjności ustalenia wynagrodzenia inkasenta $\mathrm{w}$ sytuacji gdy zarządzono pobór opłat lokalnych w drodze inkasa". Ponadto Wojewódzki Sąd Administracyjny wskazał, że „zgodnie z powyższym uregulowaniem rada gminy może ustalać wynagrodzenie dla

${ }^{45}$ D. Michta, L. Pankrac, Podatki i opłaty lokalne...op.cit., s. 119.

46 A. Ciąglewicz-Miśta, N. Ciąglewicz, A. Talik, Podatki $i$ opłaty lokalne. Komentarz ...op.cit., s. 70 .

${ }^{47}$ Sygn. II FSK 1008/06, CBOSA.

48 P. Borszowski, Ustawa o podatkach $i$ opłatach lokalnych. Komentarz, LexisNexis, Warszawa 2011, s. 249.

${ }^{49}$ Sygn. I SA/Op 277/09, CBOSA. 
płatników lub inkasentów z tytułu poboru podatków stanowiących dochody, odpowiednio, budżetu gminy, powiatu lub województwa. Brzmienie powyższego zapisu nie budzi zatem żadnych wątpliwości, że skoro rada gminy może ustalać wynagrodzenie inkasentów, to mamy do czynienia z uprawnieniem fakultatywnym, a nie o charakterze obligatoryjnym".

Ustawodawca wprowadzając przepis art. 19 ustawy pozwala gminom na samodzielność $\mathrm{w}$ zakresie ustalaniu zasad poboru i terminów płatności opłaty od posiadania psów. Z uwagi na swobodę jaką daje ustawodawca gminie istnieje pewna dowolność w ustalaniu zasad poboru i terminów płatności opłaty od posiadania psów ${ }^{50}$.

Ustawodawca $\mathrm{w}$ podatkach i opłatach lokalnych przewiduje cały szereg zwolnień o zróżnicowanym charakterze, które dotyczącą wielu danin publicznych. W głównej mierze są to zwolnienia ze względów społecznych, ale także o naturze gospodarczej oraz wspierające ekologię. Obok obligatoryjnych zwolnień przyjętych przez prawodawcę rada gminy posiada prawo do poszerzenia katalogu, który został zawarty $\mathrm{w}$ ustawie $\mathrm{z}$ tym, że nowe zwolnienia mogą mieć charakter wyłącznie przedmiotowy. $\mathrm{W}$ praktyce występują liczne problemy $\mathrm{z}$ formułowaniem poprawnych przepisów, dlatego też zasadne jest sprecyzowanie zwolnień przedmiotowych $\mathrm{w}$ tym zakresie. Zasadniczą różnicą między zwolnieniami jest fakt, że zwolnienia o charakterze przedmiotowym występują w sytuacji, gdy regulacja prawna nie opisuje wprost podmiotu objętego zwolnieniem, lecz posiłkuje się kryterium wybranych cech przedmiotu opłaty. Krótko mówiąc, zwolnienia się z przedmiotu danej opłaty pewną kategorię zdarzeń faktycznych i prawnych. Natomiast zwolnienia natury podmiotowej polegają na wykluczeniu pewnej grupy podmiotów spośród ogółu podatników ${ }^{51}$.

Wyłączenia dotyczące opłaty od posiadania psów, jakie oferuje mam prawodawca, prezentowane są $\mathrm{w}$ art. 18a ust. 2 ustawy o podatkach i opłatach lokalnych. Zatem obligatoryjnym zwolnieniem z uiszczania opłaty podlegają:

${ }^{50}$ R. Dowgier, L. Etel, B. Pahl, M. Popławski, Leksykon podatków i opłat lokalnych: 517 pytań i odpowiedzi, Wolters Kluwer Polska Sp. z o.o., Warszawa 2010, s. 532.

51 A. Ciąglewicz-Miśta, N. Ciąglewicz, A. Talik, Podatki i optaty lokalne. Komentarz ... op.cit, s. 70. 
Robert Kwaśniewski, Magdalena Jarczuk - O psach i podatkach...

1) członkowie personelu przedstawicielstw dyplomatycznych, urzędów konsularnych oraz inne osoby zrównane $\mathrm{z}$ nimi na podstawie ustaw, umów, bądź zwyczajów międzynarodowych, jeżeli nie są obywatelami polskimi i nie mają stałego miejsca pobytu na terytorium Rzeczypospolitej Polskiej - pod warunkiem wzajemności. Omawiany przepis jest konsekwencją prawną międzynarodowych regulacji52.

2) osoby zaliczane do znacznego stopnia niepełnosprawności w rozumieniu przepisów ustawy z dnia 27 sierpnia $1997 \mathrm{r}$. o rehabilitacji zawodowej i społecznej oraz zatrudnianiu osób niepełnosprawnych ${ }^{53}$, a wyłączenie dotyczy posiadania tylko jednego psa. Przy czym, za taką osobę uważa się człowieka z naruszoną sprawnością organizmu, bądź niezdolnego do pracy albo zdolnego jedynie $\mathrm{w}$ warunkach pracy chronionej i wymagającego stałej lub długotrwałej opieki i pomocy innych osób w nawiązaniu z niezdolnością do samodzielnej egzystencji,

3) osoby niepełnosprawne z tytułu posiadania psa asystującego. Zgodnie $\mathrm{z}$ wyżej wskazaną ustawą są to osoby, których niepełnosprawność została potwierdzona, z którymś z odpowiednich orzeczeń:

a) zakwalifikowaniu przez organy orzekające do jednego z trzech stopni niepełnosprawności,

b) całkowitej lub częściowej niezdolności do pracy,

c) niepełnosprawności, wydanym przed ukończeniem 16 roku życia. W tym przypadku ustawodawca postanawia wyłączyć spod opodatkowania psa kwalifikowanego. Pod pojęciem psa asystującego należy pojmować psa właściwie wyszkolonego oraz specjalnie oznaczonego, który może być przewodnikiem osoby niewidomej, niedowidzącej, a także psa asystenta osoby niepełnosprawnej ruchowo, który pomaga w życiu społecznym $^{54}$.

${ }^{52}$ P. Borszowski, Ustawa o podatkach i oplatach lokalnych. Komentarz ...op.cit., s. 243.

${ }^{53}$ Tekst jedn.: Dz. U. z 2010 r., Nr 214, poz. 1407 z późn. zm.

${ }^{54}$ P. Borszowski, Ustawa o podatkach i oplatach lokalnych. Komentarz ...op.cit., s. 245-246. 
1) osoby w wieku powyżej 65 lat prowadzących samodzielnie gospodarstwo domowe, ale tylko z tytułu posiadania jednego psa. W tym przypadku prawodawca przyjął dwa kryteria, tj. wiek oraz fakt samodzielnego prowadzenia gospodarstwa domowego. W związku z tym, że nie zostało określone pojęcie samodzielnego prowadzenia gospodarstwa domowego, niezbędna jest każdorazowa weryfikacja wszelkich indywidualnych przypadków. Koniecznością jest uwzględnienie faktu samodzielnego zamieszkania oraz sposobu wykonywania czynności związanych prowadzeniem domostwa. Natomiast problem może zaistnieć w sytuacji, gdy osoby trzecie pomagają w utrzymaniu gospodarstwa domowego, ale razem nie zamieszkują 55 .

2) podatnicy podatku rolnego od gospodarstw rolnych $\mathrm{z}$ tytułu posiadania nie więcej niż dwóch psów. W tej regulacji istotne jest czy dany podmiot mieści się $\mathrm{w}$ definicji podatnika $\mathrm{w}$ ustawie $\mathrm{z}$ dnia 15 listopada 1984 roku o podatku rolnym ${ }^{56}$.

\section{Podsumowanie}

Obowiązująca od 1 stycznia 2008 roku opłata od posiadania psów ma charakter fakultatywny, a o jej wprowadzeniu decyduje rada gminy w drodze uchwały będącej aktem prawa miejscowego. Organ stanowiący gminy podejmując decyzję o wprowadzeniu omawianej daniny publicznej na swój teren musi uprzednio zweryfikować jej opłacalność ze względów finansowych uwzględniając przy tym cele pozafiskalne ${ }^{57}$.

W praktyce opłaty lokalne, w tym opłata od posiadania psów, stanowią niski dochód publiczny, dlatego też gminy decydując się na wprowadzenie tej opłaty biorą pod uwagę funkcje administracyjnoporządkowe, a pozyskiwanie środków finansowych staje się dla nich sprawą drugorzędną ${ }^{58}$. Jednakże nie powinno być tak, że fiskalna funkcja danin

\footnotetext{
${ }^{55}$ Ibidem, s. 246.

${ }^{56}$ Tekst jedn.: Dz. U. z 2016r., poz. 617.

${ }^{57}$ R. Dowgier, Podatki $i$ opłaty lokalne: 601 pytań $i$ odpowiedzi, LEX a Wolters Kluwer business, Warszawa 2012, s. 659.

${ }^{58}$ C. Kosikowski, J. Matuszewski, Opodatkowanie posiadania psów... op.cit., s. 164.
} 
Robert Kwaśniewski, Magdalena Jarczuk - O psach i podatkach...

publicznych jest całkowicie zapomniana, gdyż to właśnie ona jest fundamentem ich istnienia i funkcjonowania. W sytuacji, gdy całkowicie zabraknie wskazanej funkcji, opłatę należy jak najszybciej usunąć z lokalnego prawa podatkowego, aby nie rodziła zbytecznych kosztów. Rozpatrując fiskalną funkcję daniny publicznej występującej w przepisach prawa podatkowego trzeba mieć na względzie koszty poboru, pewność i gwarancję jej wpływu, a przede wszystkim szerokorozumianą efektywność. Należy przyjąć, że organ gminy, który zobowiązany jest do stanowienia lokalnego prawa podatkowego powinien uwzględnić związek między korzyścią płynącą z wprowadzenia opłaty (tj. osiągniętymi przychodami) a poniesionymi nakładami, które stanowią koszty jej uzyskania. $\mathrm{Na}$ podstawie wskazanej relacji organ gminy powinien zdecydować czy opłata ta będzie przynosić fiskalne i pozafiskalne korzyści, czy też będzie zbędnym finansowym obciążeniem budżetu samorządu ${ }^{59}$.

Opłata od posiadania psów co i rusz spotyka się z falą krytyki, zarówno ze strony społeczeństwa jak i samorządów, które podejmując stosowną uchwałę stają się zobowiązane do jej egzekwowania. Kluczowym problemem okazują się trudności z jej poborem, co w rezultacie prowadzi do rezygnacji gmin z daniny publicznej, która staje się po prostu nieefektywna. Kiedy to w 2008 roku ustawodawca przekształcił podatek od posiadania psów w opłatę i tym samym nadał daninie fakultatywny charakter wiele polskich miast zdecydowało się na niewprowadzenie opłaty, a gminy które początkowo podjęły próby jej egzekwowania stopniowo rezygnują z jej funkcjonowania. Przykładem jest miasto Toruń, które w 2013 roku zrezygnowało z poboru opłaty od posiadania psów, gdyż koszty związane z prowadzeniem postępowań podatkowych i windykacyjno-egzekucyjnych przerosły wpływy z tej opłaty ${ }^{60}$. Z tego względu ustawodawca powinien się zastanowić, czy funkcjonowanie takiej opłaty od posiadania psów w obecnym systemie prawnym jest naprawdę konieczne, czy samorządy gminne mogą sobie poradzić z wydatkami bez jej wprowadzania, a potem egzekwowania?

59 J. Politowicz, Funkcje i efektywność opłaty od posiadania psów ...op.cit., s. $117-118$.

${ }^{60}$ Ibidem, s. 122. 


\section{Bibliografia:}

Borszowski P., Ustawa o podatkach $i$ opłatach lokalnych. Komentarz, LexisNexis, Warszawa 2011.

Brzeziński B., Wprowadzenie do prawa podatkowego, TNOiK Dom Organizatora, Toruń 2008.

Ciąglewicz-Miśta A., Ciąglewicz N., Talik A., Podatki $i$ opłaty lokalne. Komentarz. Projekty uchwał. Orzecznictwo, C.H.BECK, Warszawa 2011.

Dowgier R., Etel L., Pahl B., Popławski M., Leksykon podatków i opłat lokalnych: 517 pytań i odpowiedzi, Wolters Kluwer Polska Sp. z o.o., Warszawa 2010.

Dowgier R., Podatki i opłaty lokalne: 601 pytań i odpowiedzi, LEX a Wolters Kluwer business, Warszawa 2012.

Etel L., Dowgier R., Podatki i opłaty lokalne - czas na zmiany, Naukowa Rada Wydawnicza Temida 2, Białystok 2013.

Etel L., Presnarowicz S., Podatki i opłaty samorzqdowe. Komentarz, Dom Wydawniczy ABC, Warszawa 2003.

Kosikowski C., Ruśkowski E., Finanse i prawo finansowe, Wyd. 3 z aneksem, Warszawa 1994.

Kosikowski C., Matuszewski J., Opodatkowanie posiadania psów czyli płacz ze śmiechu wokół buty, Dom Wydawniczy ABC, Warszawa 2002.

Krzywoń A., Podatki i inne daniny publiczne w Konstytucji Rzeczypospolitej Polskiej, Wojskowa Drukarnia w Łodzi, Warszawa 2011. 